\title{
Human neutrophils permeabilized with digitonin respond with lysosomal enzyme release when exposed to micromolar levels of free calcium
}

\author{
James E. Smolen, Sally J. Stoehr and Laurence A. Boxer \\ Division of Pediatric Hematology / Oncology, University of Michigan Medical School, C.S. Mott Children's Hospital, Box \\ 66, Ann Arbor, MI 48109 (U.S.A.)
}

(Received September 26th, 1985)

Key words: Digitonin; Enzyme release; $\mathrm{Ca}^{2+}$; Permeabilized cell; (Neutrophil)

We have recently reported that human neutrophils can be permeabilized with the cholesterol complexing agent saponin and that these cells can be induced to secrete the granule enzyme lysozyme in response to micromolar levels of free calcium. We now report that digitonin can be used in place of saponin and that it has several advantages. Permeabilization of human neutrophils was accomplished with $10 \mu \mathrm{g} / \mathrm{ml}$ digitonin in a high potassium medium. Normally impermeant solutes such as $\left[{ }^{14} \mathrm{C}\right]$ sucrose and inulin $\left[{ }^{14} \mathrm{C}\right]$ carboxylic acid gained access to one half of the intracellular water space marked with $\left[{ }^{3} \mathrm{H}\right] \mathrm{H}_{2} \mathrm{O}$. Between 30 and $100 \%$ of the cytoplasmic enzyme, lactate dehydrogenase, leaked from the intracellular space. The permeabilization process and calcium-triggered granule secretion were critically dependent upon temperature, time and digitonin concentration. Permeabilized neutrophils secreted $\beta$-glucuronidase, lysozyme and vitamin B-12 binding-protein, constituents of both azurophil and specific granules, when exposed to micromolar levels of free calcium. Release of specific granule constituents appeared to be more sensitive to free calcium than release from azurophil granules. Although the amount of permeabilization varied considerably with each batch of cells, release of these granule markers was a consistent finding. Release of granule markers was accompanied by resealing of the cells to high-molecular-weight $\left(M_{\mathrm{r}}>\mathbf{5 0 0 0}\right)$ solutes. Electron microscopic evidence also suggested that granule and plasma membranes were intact following digitonin treatment and that fusion of these membranes occurred in response to calcium. These results suggest that elevation of intracellular free-calcium levels is a sufficient condition for lysosomal enzyme release.

\section{Introduction}

Stimulation of neutrophils leads to a variety of responses, including the secretion of lysosomal enzymes and the generation of reactive derivatives of oxygen, such as superoxide anion $\left(\mathrm{O}_{2}^{-}\right)$and $\mathrm{H}_{2} \mathrm{O}_{2}$. The agents which stimulate these responses generally interact with the plasma membrane or its receptors, triggering changes in membrane electrochemical potential $[1,2]$, cation fluxes [3-6] and

Abbreviations: PMA, 4 $\beta$-phorbol 12-myrisate 13-acetate; fMet-Leu-Phe, formylmethionylleucylphenylalanine. cyclic nucleotide levels $[7,8]$. Recent studies from this group and others have focused on the biochemical and physiologic events which serve to translate interactions at the plasma membrane level into cellular responses, i.e., on the identity of the second messenger(s).

There is now substantial evidence suggesting that intracellular calcium is playing a second messenger role in stimulus-response coupling in neutrophils. The involvement of intracellular free calcium was first suggested by studies using the probe chlortetracycline, which is generally believed to monitor membrane-bound calcium levels. The 
rapid drop in fluorescence observed when chlortetracycline-loaded cells are exposed to stimulation indicates that membrane-bound deposits are being mobilized at a very early time in the stimulus-response coupling pathway [9-11]. The fact that these fluorescence responses are not inhibited by EGTA $[9,10]$ emphasizes the intracellular nature of this response. Studies with the fluorescent intracellular calcium probe quin 2 have indicated that following stimulation with the chemotactic peptide fMet-Leu-Phe, intracellular free-calcium levels rise almost immediately from a resting level of $0.1 \mu \mathrm{M}$ to approx. $1 \mu \mathrm{M}[6,12,13]$. A substantial rise is also observed in the presence of EGTA, suggesting that intracellular stores of calcium can be mobilized. One of the few stimuli which apparently do not provoke an increase in intracellular free-calcium concentrations is the tumor promotor $4 \beta$-phorbol 12-myristate 13-acetate (PMA; Refs. 14 and 15). Even in this case, intracellular free calcium may underlie the activation process. PMA reduces the $K_{\mathrm{m}}$ for calcium of its putative receptor, protein kinase $\mathrm{C}$, into the submicromolar range [16]. With these altered kinetics, the kinase could be activated by the 'resting' levels of intracellular free calcium.

Thus, there is ample evidence that intracellular free calcium levels increase in stimulated neutrophils. However, to substantiate a second messenger role of calcium, it is necessary to show that micromolar levels of intracellular free calcium are sufficient to induce stimulation of the cells. In other secretory systems, permeabilization has been employed to introduce calcium buffers into the cytoplasm and otherwise manipulate the interior of the cells [17-23]. In general, these investigations have demonstrated that micromolar levels of intracellular free calcium are adequate to induce secretion from a variety of cell types. Indeed, we have recently reported that human neutrophils can be permeabilized with the cholesterol-complexing agent saponin [24]; these permeabilized neutrophils can be induced to secrete the lysosomal enzyme lysozyme in response to micromolar levels of free calcium. However, cells permeabilized with this agent are quite fragile and do not secrete any azurophil granule constituents. Moreover, saponin is a poorly defined material. We now report that human neutrophils can be permeabilized with the defined cholesterol-complexing agent digitonin, and that these cells can be induced to secrete lysosomal constituents when exposed to micromolar levels of free calcium. Furthermore, lysosomal enzyme release can be obtained from both the specific and azurophil granules. These data demonstrate that increases in intracellular free calcium into the micromolar range constitute a sufficient condition for secretion.

\section{Materials and Methods}

Reagents. Calmodulin (from bovine brain), cyclic AMP (sodium salt), cyclic GMP (sodium salt), ATP (disodium salt, vanadium free), GTP (type 1) and digitonin (lot 62F0135) were purchased from Sigma Chemical Company, St. Louis, MO. Inulin $\left[{ }^{14} \mathrm{C}\right]$ carboxylic acid and $\left[{ }^{3} \mathrm{H}\right] \mathrm{H}_{2} \mathrm{O}$ were obtained from New England Nuclear, Boston, MA. $\left[{ }^{14}\right.$ C]EDTA was obtained from Amersham, Arlington Heights, IL. Hydrofluor was purchased from National Diagnostics, Somerville, NJ. All other materials were reagent grade.

Preparation of cell suspensions. Heparinized (10 units $/ \mathrm{ml}$ ) venous blood was obtained from healthy adult donors. Purified preparations of neutrophils were isolated from this blood by means of $\mathrm{Hy}$ paque/Ficoll gradients [25] followed by standard techniques of dextran sedimentation and hypotonic lysis of erythrocytes [26]. This allowed studies of cell suspensions containing $98 \pm 2 \%$ neutrophils with few contaminating platelets or erythrocytes. The cells were washed and finally suspended in buffer $\mathrm{A}(138 \mathrm{mM} \mathrm{NaCl} / 2.7 \mathrm{mM}$ $\mathrm{KCl} / 8.1 \mathrm{mM} \quad \mathrm{Na}_{2} \mathrm{HPO}_{4} / 1.5 \mathrm{mM} \quad \mathrm{KH}_{2} \mathrm{PO}_{4} / 1$ $\mathrm{mM} \mathrm{MgCl} / 2 / 0.6 \mathrm{mM} \mathrm{CaCl}_{2}$ (pH 7.4). For permeabilization studies, the cells were instead washed once and resuspended in buffer $B(100 \mathrm{mM} \mathrm{KCl}$ / $20 \mathrm{mM} \mathrm{NaCl} / 1 \mathrm{mM}$ EGTA/30 mM Hepes (pH 7.0)).

Neutrophil permeabilization. Stock solutions of digitonin from a single lot $(1 \mathrm{mg} / \mathrm{ml})$ were prepared daily in buffer $B$; the resulting suspension was more efficient than solutions clarified by heating. Neutrophils $\left(25 \cdot 10^{6} / \mathrm{ml}\right)$ suspended in buffer $B$ were preincubated for $10 \mathrm{~min}$ at $37^{\circ} \mathrm{C}$. Incubation was at $37^{\circ} \mathrm{C}$ for $25 \mathrm{~min}$ with $10 \mu \mathrm{g} / \mathrm{ml}$ digitonin, unless otherwise indicated; the cell sus- 
pension was mixed every $5 \mathrm{~min}$. For monitoring of permeabilization, $\left[{ }^{3} \mathrm{H}_{3} \mathrm{H}_{2} \mathrm{O}(1 \mu \mathrm{Ci} / \mathrm{ml})\right.$ was included as an intracellular space marker: inulin $\left[{ }^{14} \mathrm{C}\right]$ carboxylic acid $(1 \mu \mathrm{Ci} / \mathrm{ml}, 0.01 \mathrm{mM})$ or $\left[{ }^{14} \mathrm{C}\right]$ EDTA $(1 \mu \mathrm{Ci} / \mathrm{ml}, 0.1 \mathrm{mM})$ were included as extracellular space markers. After various times of incubation, $200-\mu 1$ aliquots of sample were placed in $400-\mu \mathrm{l}$ polyethylene centrifuge tubes (Beckman Instruments) which already contained $100 \mu 1$ silicone oil layered over $100 \mu 1$ of $85 \%$ phosphoric acid. Centrifugation for $20 \mathrm{~s}$ at $9000 \times$ $g$ in a Beckman Microfuge B sedimented the neutrophils through the oil into the phosphoric acid. The tips of the tubes were excised and the cell digests were placed in $1 \mathrm{ml}$ of water. Vigorous shaking dislodged the cell layer, $10 \mathrm{ml}$ of hydrofluor was added, and the digest was counted in a Tracor Analytic model 6972 liquid scintillation counter.

The following procedures were employed for studies of reversibility. When Trypan blue was used as a marker, permeabilized cells were exposed to the desired concentrations of $\mathrm{Ca}^{2+}$ for $10 \mathrm{~min}$ at $37^{\circ} \mathrm{C}$. Trypan blue was added, allowed to equilibrate for $10 \mathrm{~min}$, after which the percentage of cells positive for Trypan blue was counted. Control cells were defined as those to which no $\mathrm{Ca}^{2+}$ was added. When radiochemical tracers were used as markers, the permeabilized cells were treated and equilibrated with the probes as described for Trypan blue. Ratios of $\left[{ }^{3} \mathrm{H}\right] \mathrm{H}_{2} \mathrm{O} /{ }^{14} \mathrm{C}$-labeled solute were determined. The ratio for non-permeabilized cells was statistically indistinguishable from that for permeabilized cells resealed with $1 \cdot 10^{-4}$ $\mathrm{M} \mathrm{Ca}^{2+}$, using $\left[{ }^{14} \mathrm{C}\right]$ inulin as the tracer; this latter datum was defined as $100 \%$ reversibility. The ratios for permeabilized neutrophils which were not exposed to $\mathrm{Ca}^{2+}$ (control cells) were defined as $0 \%$ reversibility. All other values for percent reversibility were calculated from these data.

Lysosomal enzyme release. Following permeabilization, neutrophils were suspended in buffer $B$ at a concentration of $5 \cdot 10^{6} / \mathrm{ml}$ and then incubated with calcium (final free concentrations of $0.25-100 \mu \mathrm{M}$ ) at $37^{\circ} \mathrm{C}$ for $10 \mathrm{~min}$. All of these conditions could be varied, as indicated. Cells incubated without calcium and unpermeabilized neutrophils were employed as routine controls. The cell suspensions were then centrifuged at 750 $\times g$ for $10 \mathrm{~min}$ or $9000 \times g$ for $20 \mathrm{~s}$ in a Beckman Microfuge (depending upon the experimental protocol). Aliquots of the supernatants were taken for standard determinations of $\beta$-glucuronidase [27], lysozyme [28] vitamin B-12 binding protein [29] and lactate dehydrogenase activities [39].

Free-calcium determinations. Free-calcium determinations for buffer B supplemented with 2 . $10^{-4}-1.2 \cdot 10^{-3} \mathrm{M}$ total $\mathrm{Ca}^{2+}$ were made using a calcium-sensitive electrode (Orion 93-20). Titration curves were established for calcium solutions in the $1 \cdot 10^{-5} \mathrm{M}-2 \cdot 10^{-2} \mathrm{M} \mathrm{Ca}^{2+}$ range and the slope of the electrode was assumed to be constant for free-calcium concentrations below $1 \cdot 10^{-5} \mathrm{M}$ [31]. In all cases where buffer $B$ was supplemented (i.e., with ATP, GTP, $\mathrm{Mg}^{2+}$, etc.) or altered $(\mathrm{pH})$, separate titration curves were generated. The calcium contributed by the endogenous contents of neutrophils could not significantly alter final free-calcium concentrations.

Electron microscopy. Neutrophils suspended in buffer $\mathrm{B}$ were permeabilized with digitonin and then stimulated for $5 \mathrm{~min}$ with $30 \mu \mathrm{M}$ free $\mathrm{Ca}^{2+}$. Aliquots of these cells were fixed in a solution containing 3\% glutaraldehyde, $3 \%$ formaldehyde and $100 \mathrm{mM}$ sodium cacodylate. Postfixation was in $2 \% \mathrm{OsO}_{4}$ buffered with $S$-colloidin, and embedding in agar. Agar pellets were embedded in Epon 812 and stained en bloc with 2\% uranyl acetate. Ultrathin sections were cut using a Sorvall Porter Blum MT2-B ultramicrotome equipped with a diamond knife. Sections were stained with Reynold's lead citrate stain and viewed with a Zeiss 109TFP transmission electron microscope.

\section{Results}

\section{Conditions for optimal permeation of tracers}

We previously demonstrated that human neutrophils could be permeabilized with the cholesterol-complexing agent, saponin, and that these permeabilized cells could be induced to secrete the granule enzyme lysozyme in response to elevated levels of free calcium [24]. This system has some weaknesses which proved to be ameliorated by using digitonin in place of saponin. A crucial first step for establishing the conditions for permeabilization by any agent is the use of radiochemical tracers. In these studies we em- 


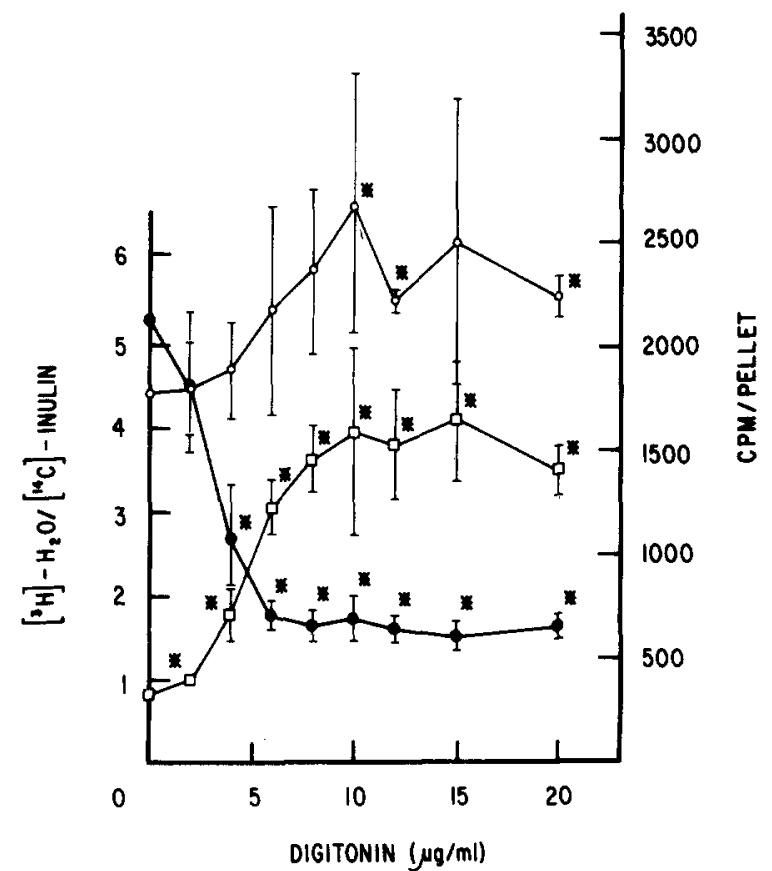

Fig. 1. The effects of digitonin concentration on the distribution of intracellular and extracellular space markers. Human neutrophils were preincubated with the indicated concentrations of digitonin for $25 \mathrm{~min}$ at $37^{\circ} \mathrm{C}$ in the presence of radiochemical tracers. The cell pellet was obtained by centrifugation through silicone oil. Radioactivity in the isolated cell pellet was determined. The data are given as the means $( \pm$ S.D.) for three separate experiments and show ${ }^{14} \mathrm{C}$-labelled extracellular space markers and $\left[{ }^{3} \mathrm{H}_{3} \mathrm{H}_{2} \mathrm{O}\right.$ distributions. The ratio of the volumes marked by these tracers is also given. The asterisks indicate significance to the $P<0.05$ level using the Student's paired t-test. $\left.-\square,\left[{ }^{3} \mathrm{H}\right] \mathrm{H}_{2} \mathrm{O} / \mathrm{I}^{14} \mathrm{C}\right]$ inulin; $\square-\square$, ${ }^{14} \mathrm{C} ; \mathrm{O}-\mathrm{O},{ }^{3} \mathrm{H}$.

ployed extracellular space markers such as inulin $\left[{ }^{14} \mathrm{C}\right]$ carboxylic acid or $\left[{ }^{14} \mathrm{C}\right]$ sucrose and observed whether or not treatment with digitonin permitted these tracers access to the intracellular space marked by $\left[{ }^{3} \mathrm{H}_{3} \mathrm{H}_{2} \mathrm{O}\right.$. As shown in Fig. 1, increasing concentrations of digitonin caused an increase in the number of ${ }^{14} \mathrm{C}$ counts obtained in the cell pellet. The ratio of volumes marked by ${ }^{3} \mathrm{H}$ and ${ }^{14} \mathrm{C}$ decreased to an asymptotic value of about 2 , indicating that the solute was gaining access to about one half of the water space. This is consistent with the interpretation that the solute was still being excluded from nuclei and granules. At concentrations above $30 \mu \mathrm{g} / \mathrm{ml}$ (not shown), the cells lysed, as indicated by a virtually complete collapse of the $\left[{ }^{3} \mathrm{H}\right] \mathrm{H}_{2} \mathrm{O}$ space. From these data, we selected a digitonin concentration of $10 \mu \mathrm{g} / \mathrm{ml}$ as optimal for routine permeabilization.

The time-course of permeabilization of human neutrophils with $10 \mu \mathrm{g} / \mathrm{ml}$ of digitonin was also examined (not shown). The ratio of ${ }^{3} \mathrm{H}$-to ${ }^{14} \mathrm{C}$ volumes decreased to an asymptotic value of approx. 2 as time progressed. From these data, we selected $25 \mathrm{~min}$ as a time period providing adequate permeabilization.

\section{Conditions for optimal $\mathrm{Ca}^{2+}$-induced granule secre- tion}

In view of the results obtained using the saponin system, we were interested in observing the effect of free calcium on the release of cellular constituents from the permeabilized neutrophils. Fig. 2 shows a typical experiment in which the cells were preincubated and permeabilized with digitonin for $15 \mathrm{~min}$, after which free-calcium levels of $25 \mu \mathrm{M}$ were established. As can be seen in the upper left, release of the cytosolic enzyme lactate dehydrogenase took place almost linearly over the duration of the experiment, in the absence of calcium. When calcium was added at the $15 \mathrm{~min}$ point, however, release of lactate dehydrogenase stopped abruptly, apparently due to resealing of the cells. In marked contrast, release of the azurophil granule enzyme, $\beta$-glucuronidase, took place at a much smaller rate in the absence of calcium (upper right), indicating that the granule membranes remained relatively intact. When calcium was added, however, a rapid release of a substantial fraction of the cellular $\beta$-glucuronidase was observed. No calcium-triggered release of this enzyme was observed when the cells were permeabilized with saponin [24]. As shown in the lower left, release of lysozyme, an enzyme found both in the specific and azurophil granules, was negligible in the permeabilized cells until calcium was added, after which secretion was pronounced and rapid. Similar results were obtained for the specific granule constituent, vitamin B-12 binding protein, as shown in the lower right.

Although the previous tracer studies indicated that optimal permeabilization was obtained at 25 min, it was important to see how this treatment affected lactate dehydrogenase release or calciuminduced granule secretion. Therefore, we first 


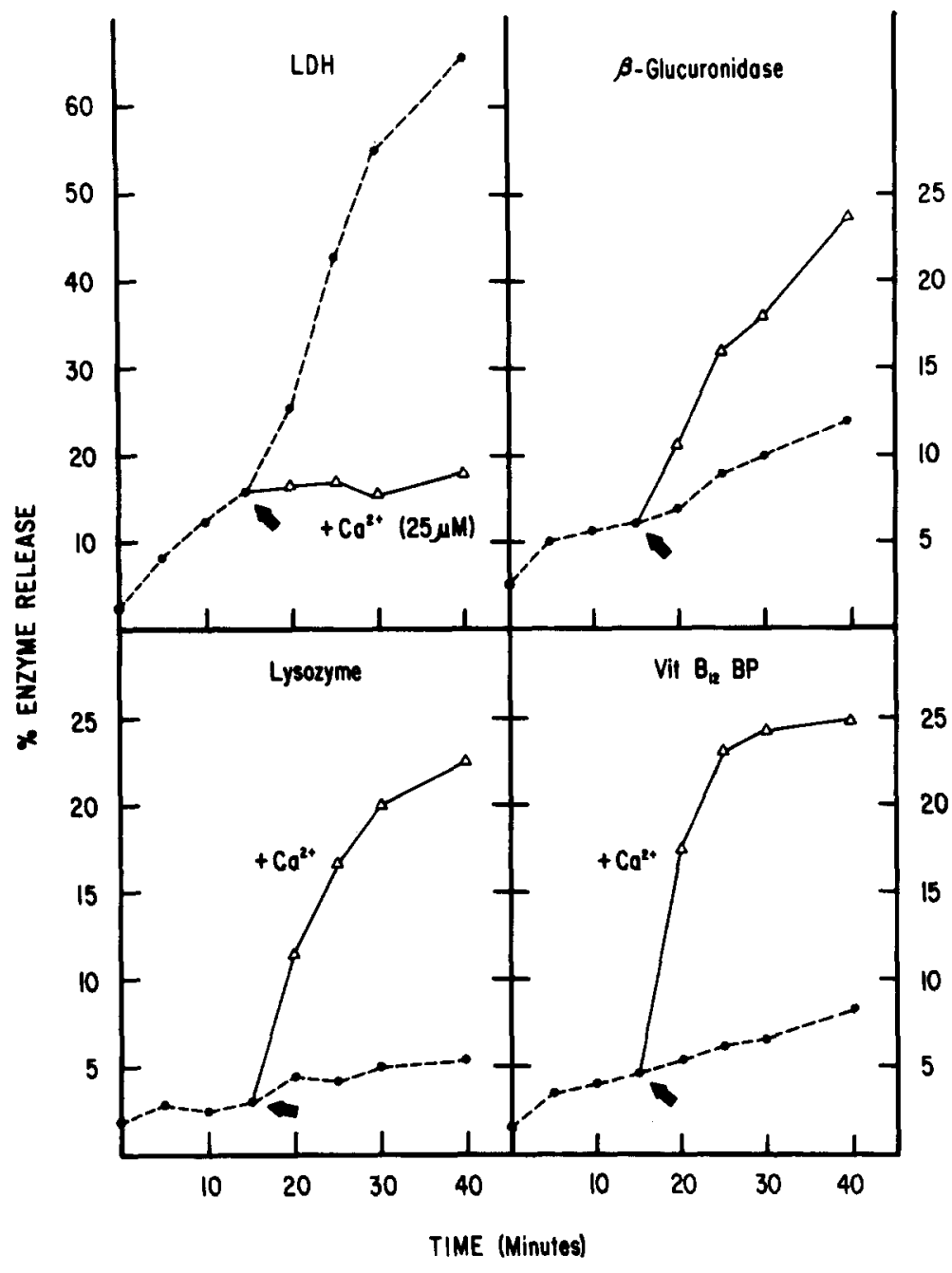

Fig. 2. Time-course of the release of cellular constituents from permeabilized neutrophils in the presence and absence of calcium. Suspensions of human neutrophils were exposed to $10 \mu \mathrm{g} / \mathrm{ml}$ digitonin and incubated at $37^{\circ} \mathrm{C}$. Samples were taken at the indicated times and cell-free supernatants were obtained by centrifugation at $8000 \times g$ in a Beckman Microfuge $B$. At the $15 \mathrm{~min}$ point, $25 \mu \mathrm{M}$ free calcium was added to half of the samples and aliquots were taken at the indicated times for the duration of the experiment. Cell-free supernatants were assayed for contents of lactate dehydrogenase (LDH), $\beta$-glucuronidase, lysozyme and vitamin B-12 binding protein activities. The data shown are from a single typical experiment (of which at least three were performed). $-\mathrm{Ca}^{2+},-$ $+\mathrm{Ca}^{2+}, \Delta-\Delta$. looked at the effect of permeabilization time on release of cellular enzymes. For the experiment shown in Fig. 3, neutrophils were permeabilized with $10 \mu \mathrm{g} / \mathrm{ml}$ digitonin for the indicated periods of time, after which they were exposed to 0 or 25 $\mu \mathrm{M}$ free calcium and incubated for an additional $7.5 \mathrm{~min}$. As expected from the tracer studies, permeabilization as monitored by lactate dehydrogenase release was strongly time dependent. Lactate dehydrogenase release was reduced if calcium was present during the $7.5 \mathrm{~min}$ incubation period, reflecting the apparent resealing process. The amount of lysosomal constituents which could be released by calcium was also strongly time dependent and appeared to require adequate permeabilization. In view of the concordance between these data, a 25 min permeabilization period was accepted as a standard incubation condition for both functional and tracer studies.

It was also important to show that the concentrations of digitonin chosen on the basis of tracer permeation were useful for studies of calcium-induced granule release. As can be seen in Fig. 4, the extent of permeabilization and responsiveness to calcium were dependent upon the concentration of digitonin employed. Release of cytoplasmic lactate dehydrogenase increased with digitonin concentration, reaching a plateau above $10 \mu \mathrm{g} / \mathrm{ml}$ (upper left). The calcium-stimulated release of the three granule constituents followed a similar pattern. Concentrations of digitonin greater than $30 \mu \mathrm{g} / \mathrm{ml}$ caused lysis of the cells, as indi- 


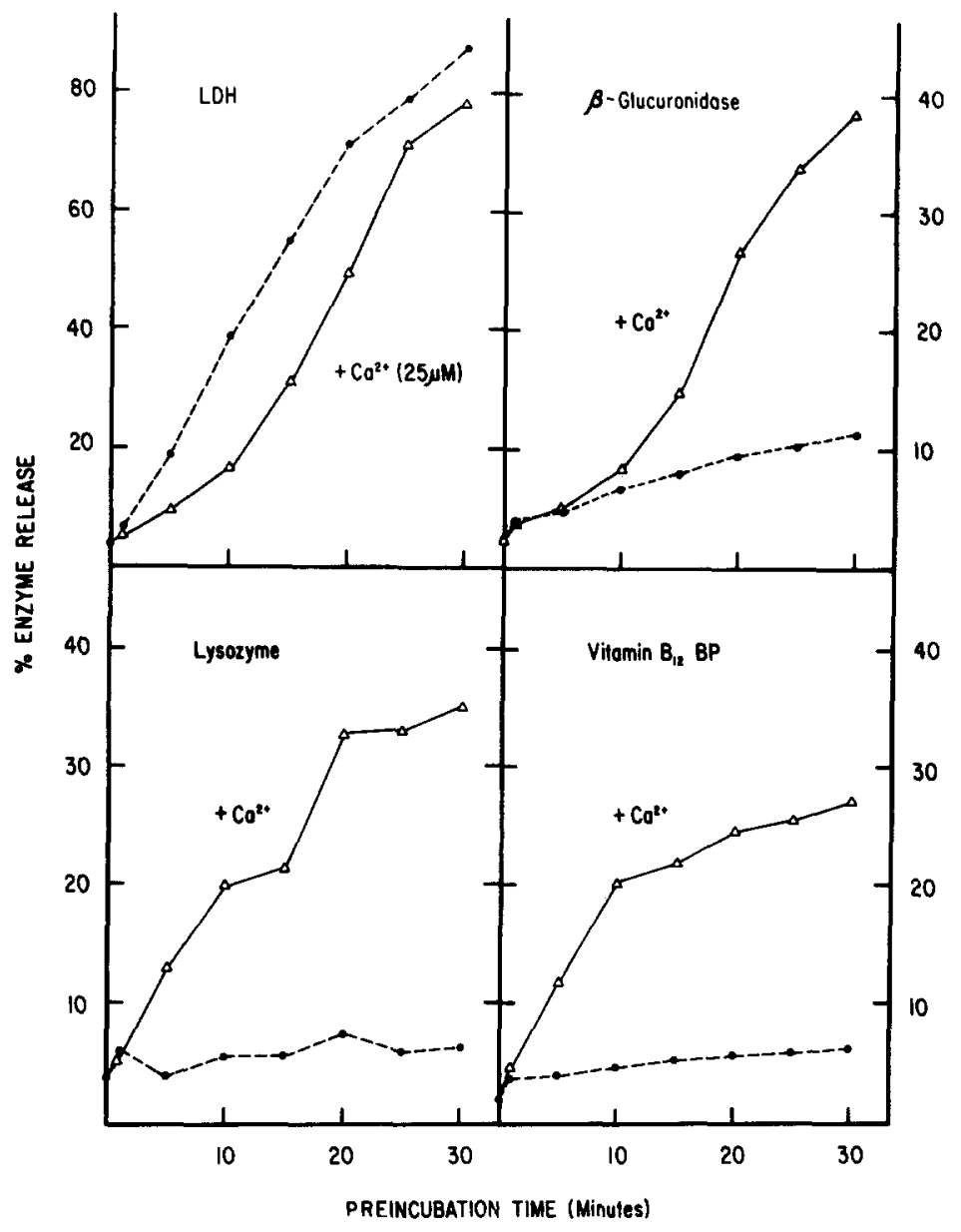

Fig. 3. Effect of preincubation time on the release of cellular constituents in the presence or absence of calcium. Human neutrophils were preincubated with digitonin $(10 \mu \mathrm{g} / \mathrm{ml})$ at $37^{\circ} \mathrm{C}$ for the indicated periods of time, after which incubation proceeded for an additional $7.5 \mathrm{~min}$ in the presence $(\Delta)$ or absence (O) of $25 \mu \mathrm{M}$ free calcium. The data are from a single typical experiment (of which at least three were performed). $\mathrm{LDH}$, lactate dehydrogenase. cated by massive release of granule constituents. These data suggested that the standard concentration of $10 \mu \mathrm{g} / \mathrm{ml}$, chosen on the basis of the tracer studies shown in Fig. 1, was also suitable for studies of lysosomal enzyme release.

Successful permeabilization, but not secretion per se, proved to be very sensitive to temperature. Fig. 5 shows a typical experiment in which neutrophils were both permeabilized and then stimulated with calcium at different temperatures. As can be seen, permeabilization (as indicated by lactate dehydrogenase release) and subsequent enzyme secretion were highly dependent upon the temperature, with $37^{\circ} \mathrm{C}$ being close to maximal. This temperature dependence was primarily a property of the permeabilization process, not of calcium-induced secretion; when the neutrophils were initially permeabilized at $37^{\circ} \mathrm{C}$ and then in- cubated with calcium at different temperatures, the pronounced temperature dependence was no longer evident (not shown). Diminished release of vitamin B-12 binding protein was found at the elevated temperatures; this could conceivably be due to degradation of this compound by enhanced proteinase and oxidant secretion obtained at these temperatures.

\section{Variability}

One problem with the digitonin permeabilization system is that the extent of permeabilization can vary widely between batches of cells. It is not yet clear if this variability is donor dependent; whatever the source of the variability, we have elected to emphasize its presence in this study by employing standard deviations rather than standard errors of the means. As can be seen in Table 


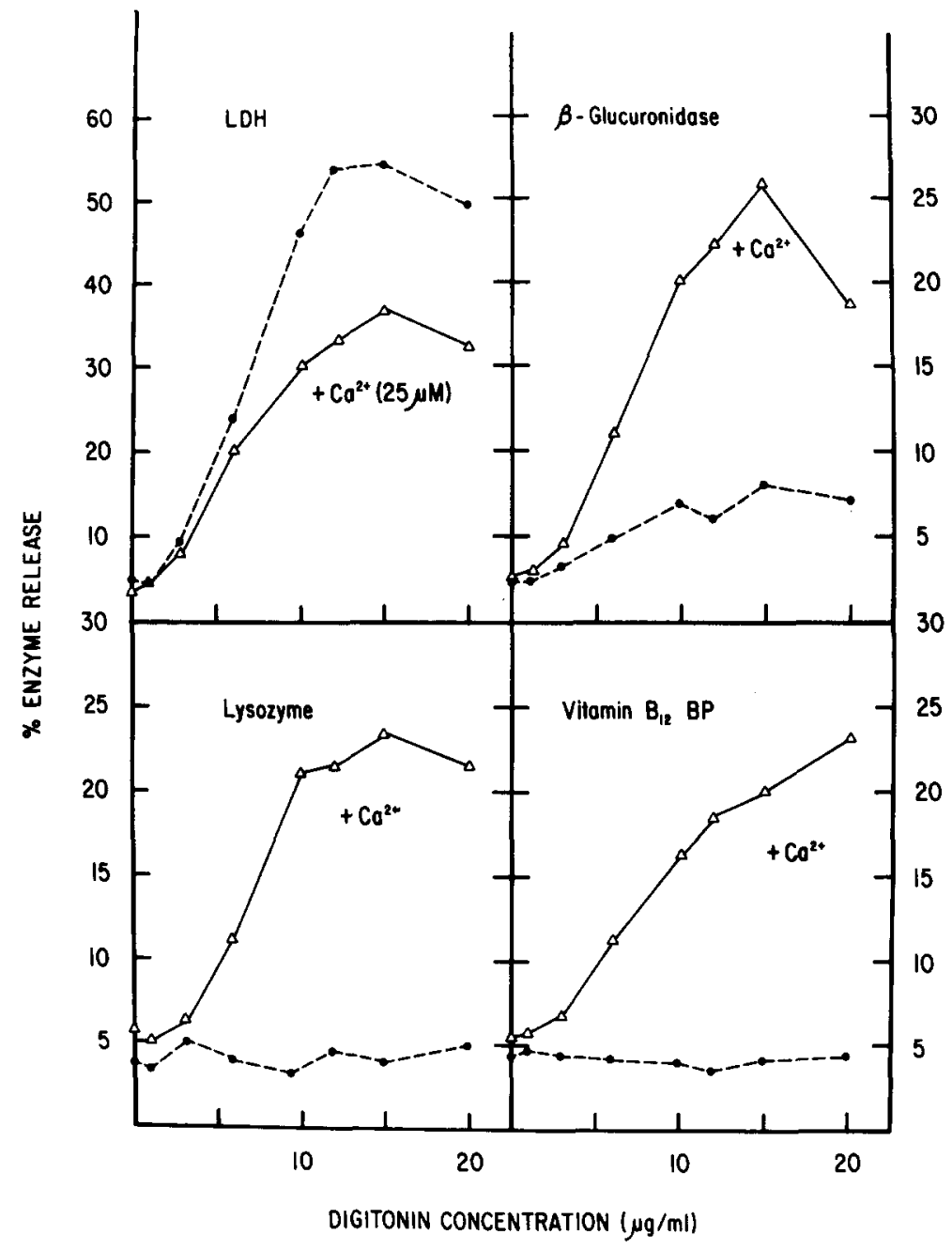

Fig. 4. Effect of digitonin concentration on the release of cellular constituents in the presence or absence of calcium. Human neutrophils were preincubated with the indicated concentrations of digitonin for $25 \mathrm{~min}$ at $37^{\circ} \mathrm{C}$, after which they were incubated with $(\Delta)$ or without (O) $25 \mu \mathrm{M}$ free calcium for an additional $10 \mathrm{~min}$. The data shown are from a single typical experiment (of which at least three were performed). LDH, lactate dehydrogenase.
I, the amount of lactate dehydrogenase release obtained in the presence of digitonin was $61 \pm 17 \%$ $(n=47)$ with a range of $119-30 \%$. Substantial variability was also found with the release of lysosomal constituents, especially after they were stimulated with calcium. However, as shown in Table I, the differences between permeabilized and calcium-stimulated releases of enzymes were highly significant, even when unpaired statistics were employed. Furthermore, the amount of calcium-induced secretion of lysosomal constituents correlated closely with the extent of permeabilization (monitored by the release of lactate dehydrogenase following treatment with digitonin). As shown in Table II, lactate dehydrogenase release from digitonin-treated cells (column entitled 'digitonin') correlated strongly with calcium-induced secretion of all three granule contents (row 3 for each granule constituent).

\section{Modulation of calcium-induced secretion}

In view of the above-mentioned variability, it was important to establish the significance of calcium-induced lysosomal enzyme release. Free calcium in the micromolar range induced statistically significant secretion of all three lysosomal constituents (Fig. 6). The release of lactate dehydrogenase was significantly decreased above 10 $\mu \mathrm{M} \mathrm{Ca}^{2+}$. Substantial and consistent enhancement of $\beta$-glucuronidase release was found only at calcium concentrations greater than $30 \mu \mathrm{M}$. Lysozyme exhibited greater sensitivity to calcium, 
TABLE I

SUMMARY OF CELLULAR CONSTITUENT RELEASE BY DIGITONIN AND SUBSEQUENT EXPOSURE TO CALCIUM

The data in this table give the means, standard deviations, numbers of experiments, degree of significance and range of results for all pooled experiments. All of the data were obtained from experiments in which permeabilization was obtained with $10 \mu \mathrm{g} / \mathrm{ml}$ digitonin for $25 \mathrm{~min}$ at $37^{\circ} \mathrm{C}$, secretion was induced by 25 or $100 \mu \mathrm{M}$ free calcium for $5-15 \mathrm{~min}$ at $37^{\circ} \mathrm{C}$. Condition 1 refers to untreated, control neutrophils. Condition 2 refers to those cells which have been permeabilized with digitonin. Condition 3 refers to permeabilized cells which were subsequently stimulated with calcium. Significance for Condition 2 refers to an unpaired Student's $t$-test comparison between Conditions 1 and 2. Significance for Condition 3 refers to a similar comparison between Conditions 2 and 3. Levels of significance: - not meaningful; *P<0.001; ** $P<10^{-5}$

\begin{tabular}{|c|c|c|c|c|c|}
\hline Enzyme & Condition & Mean \pm S.D. & $n$ & Significance & Low-high \\
\hline \multicolumn{6}{|c|}{ Lactate dehydrogenase } \\
\hline Control & 1 & $2.4 \pm 5.2$ & 38 & - & $0.7-11.8$ \\
\hline Digitonin & 2 & $61.0 \pm 17.4$ & 47 & $* *$ & $30.0-118.9$ \\
\hline Digitonin $+\mathrm{Ca}^{2+}$ & 3 & $40.5 \pm 14.2$ & 44 & $* *$ & $15.2-84.0$ \\
\hline \multicolumn{6}{|l|}{ Lysozyme } \\
\hline Control & 1 & $4.9 \pm 3.1$ & 38 & - & $-2.7-13.8$ \\
\hline Digitonin & 2 & $9.6 \pm 4.9$ & 47 & * & $3.1-28.8$ \\
\hline Digitonin $+\mathrm{Ca}^{2+}$ & 3 & $31.5 \pm 10.1$ & 44 & $* *$ & $11.5-53.4$ \\
\hline \multicolumn{6}{|c|}{ Vit. B-12 binding protein } \\
\hline Control & 1 & $5.4 \pm 3.1$ & 37 & - & $1.6-16.6$ \\
\hline Digitonin & 2 & $9.0 \pm 3.8$ & 46 & $*$ & $4.0-24.4$ \\
\hline Digitonin $+\mathrm{Ca}^{2+}$ & 3 & $24.6 \pm 6.0$ & 44 & $* *$ & $12.0-36.6$ \\
\hline \multicolumn{6}{|l|}{$\beta$-Glucuronidase } \\
\hline Control & 1 & $2.5 \pm 0.9$ & 38 & - & $0.0-4.5$ \\
\hline Digitonin & 2 & $9.4 \pm 3.5$ & 46 & $* *$ & $2.6-20.3$ \\
\hline Digitonin $+\mathrm{Ca}^{2+}$ & 3 & $23.4 \pm 9.4$ & 47 & $* *$ & $9.4-47.5$ \\
\hline
\end{tabular}

\section{TABLE II}

\section{CORRELATION BETWEEN RELEASE OF GRANULE CONSTITUENTS AND LACTATE DEHYDROGENASE AFTER EXPOSURE TO DIGITONIN AND STIMULATION WITH CALCIUM}

Data were pooled from those experiments used in Table $I$ and all the same criteria apply. The data were subjected to analysis in order to look for correlations between the permeabilization, as monitored by lactate dehydrogenase release, and secretion of granule constituents. The symbols used below are as follows: - , not significant; $*$, significant to $P<0.05$; ${ }^{* *}$, significant to $P<0.01$.

\begin{tabular}{|c|c|c|c|c|}
\hline \multirow[t]{2}{*}{ Enzyme release } & \multirow[t]{2}{*}{ Condition } & \multicolumn{3}{|c|}{ Lactate dehydrogenase } \\
\hline & & control & digitonin & digitonin $+\mathrm{Ca}^{2+}$ \\
\hline \multicolumn{5}{|l|}{ Lysozyme } \\
\hline Control & 1 & $*$ & - & - \\
\hline Digitonin & 2 & - & - & - \\
\hline Digitonin $+\mathrm{Ca}^{2+}$ & 3 & ** & $* *$ & - \\
\hline \multicolumn{5}{|c|}{ Vitamin B-12 binding protein } \\
\hline Control & 1 & $*$ & - & - \\
\hline Digitonin & 2 & - & - & - \\
\hline Digitonin $+\mathrm{Ca}^{2+}$ & 3 & $* *$ & $* *$ & $*$ \\
\hline \multicolumn{5}{|l|}{$\beta$-Glucuronidase } \\
\hline Control & 1 & - & - & - \\
\hline Digitonin & 2 & - & $* *$ & $*$ \\
\hline Digitonin $+\mathrm{Ca}^{2+}$ & 3 & $*$ & $* *$ & $* *$ \\
\hline
\end{tabular}




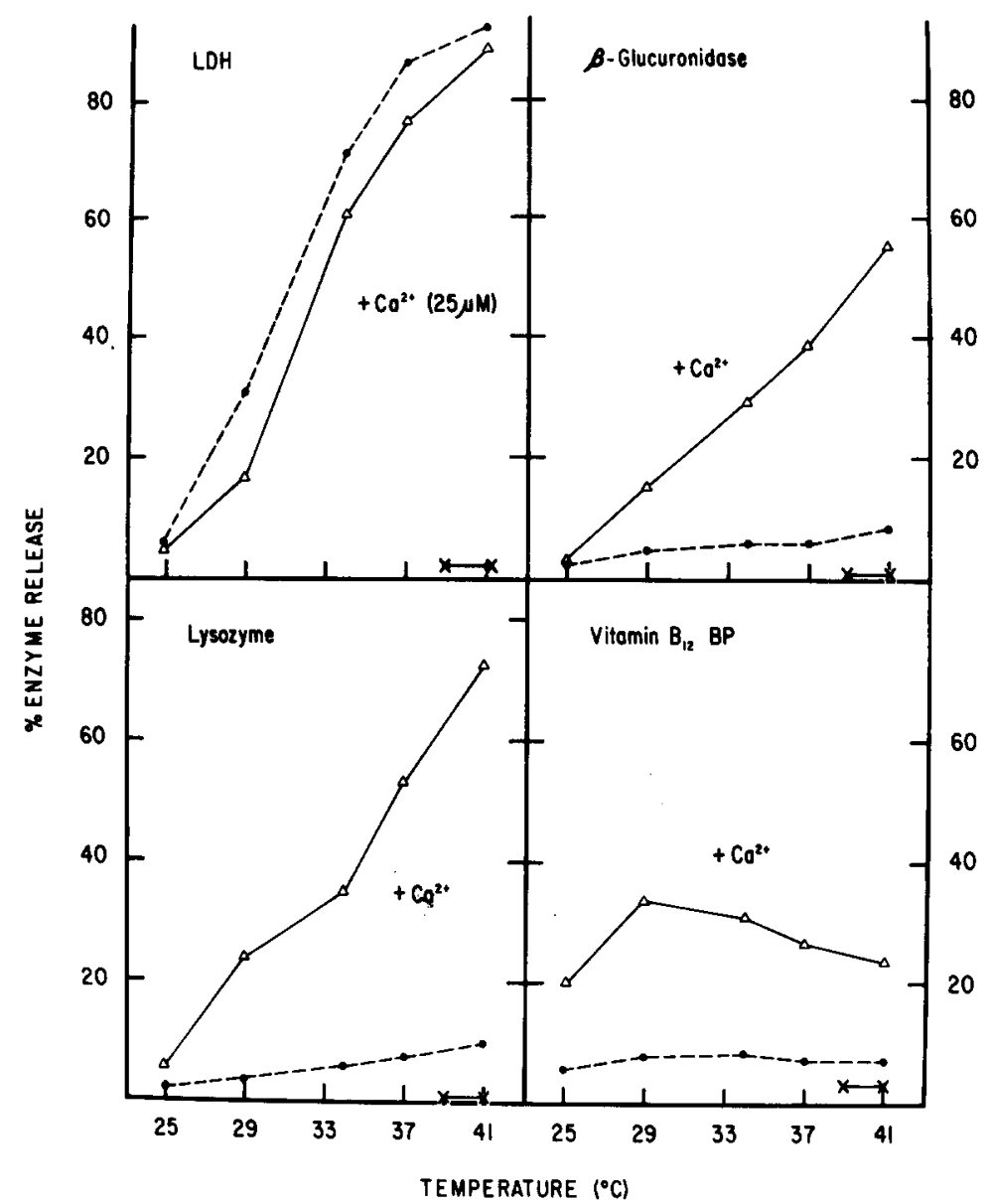

Fig. 5. Effect of temperature on permeabilization and the calcium-induced release of cellular constituents. Human neutrophils were preincubated with digitonin $(10 \mu \mathrm{g} / \mathrm{ml})$ for 25 $\mathrm{min}$ at the indicated temperature, after which they were incubated with $(\Delta)$ or without $(O)$ $25 \mu \mathrm{M}$ free calcium for an additional $10 \mathrm{~min}$ at the same temperature. The data shown are from a single typical experiment (of which at least three were performed). $\times-x$ in dicates the background level of enzyme release found in the absence of digitonin. $\mathrm{LDH}$, lactate dehydrogenase. with substantial release at greater than $10 \mu \mathrm{M}$. Vitamin B-12 binding protein, which was released at concentrations greater than 5-7 $\mu \mathrm{M}$, was the most sensitive.

A number of potential modulators of calciuminduced lysosomal enzyme release were tested for their effects upon the permeabilized cell system. In essence, we found that ATP $(5-100 \mu \mathrm{M}), \mathrm{Mg}^{2+}(1$ $\mathrm{mM})$, GTP (100 $\mu \mathrm{M})$, cAMP (50 $\mu \mathrm{M})$, cGMP (50 $\mu \mathrm{M})$, cytochalasin B $(5 \mu \mathrm{g} / \mathrm{ml})$ and colchicine (5 $\mu \mathrm{M})$ were all without profound effect upon calcium-induced secretion. This secretion also proved to be relatively independent of cell concentration (Fig. 7); this is in contrast to the results obtained with the saponin-permeabilized system [24].

\section{Reversibility of permeabilization}

The data in Fig. 2 suggest that the addition of
$\mathrm{Ca}^{2+}$ might cause resealing of the cells, as indicated by a diminution in lactate dehydrogenase release. In a series of experiments following up this lead, we treated permeabilized neutrophils with various concentrations of $\mathrm{Ca}^{2+}$ and then examined their ability to exclude Trypan blue. As shown in Fig. 8, high concentrations of $\mathrm{Ca}^{2+}$ resulted in approx. $50 \%$ of the cells becoming impermeable to Trypan blue.

Radiochemical studies with $\left[{ }^{14} \mathrm{C}\right]$ inulin and $\left[{ }^{14} \mathrm{C}\right]$ EDTA were also performed (not shown). In these experiments, the neutrophils were subjected to various treatments and then exposed to $\left[{ }^{3} \mathrm{H}_{3} \mathrm{H}_{2} \mathrm{O}\right.$ and the desired ${ }^{14} \mathrm{C}$-labelled solute. The $\left[{ }^{3} \mathrm{H}_{3} \mathrm{H}_{2} \mathrm{O}\right.$ to- $\left[{ }^{14} \mathrm{C}\right]$ inulin ratios were approx. 5, 2 and 5 for non-permeabilized, permeabilized and calciumtreated $\left(1 \cdot 10^{-4} \mathrm{M}\right)$ permeabilized cells, respectively (Fig. 1; unpublished data). This latter value was defined as $100 \%$ reversibility of permeabiliza- 


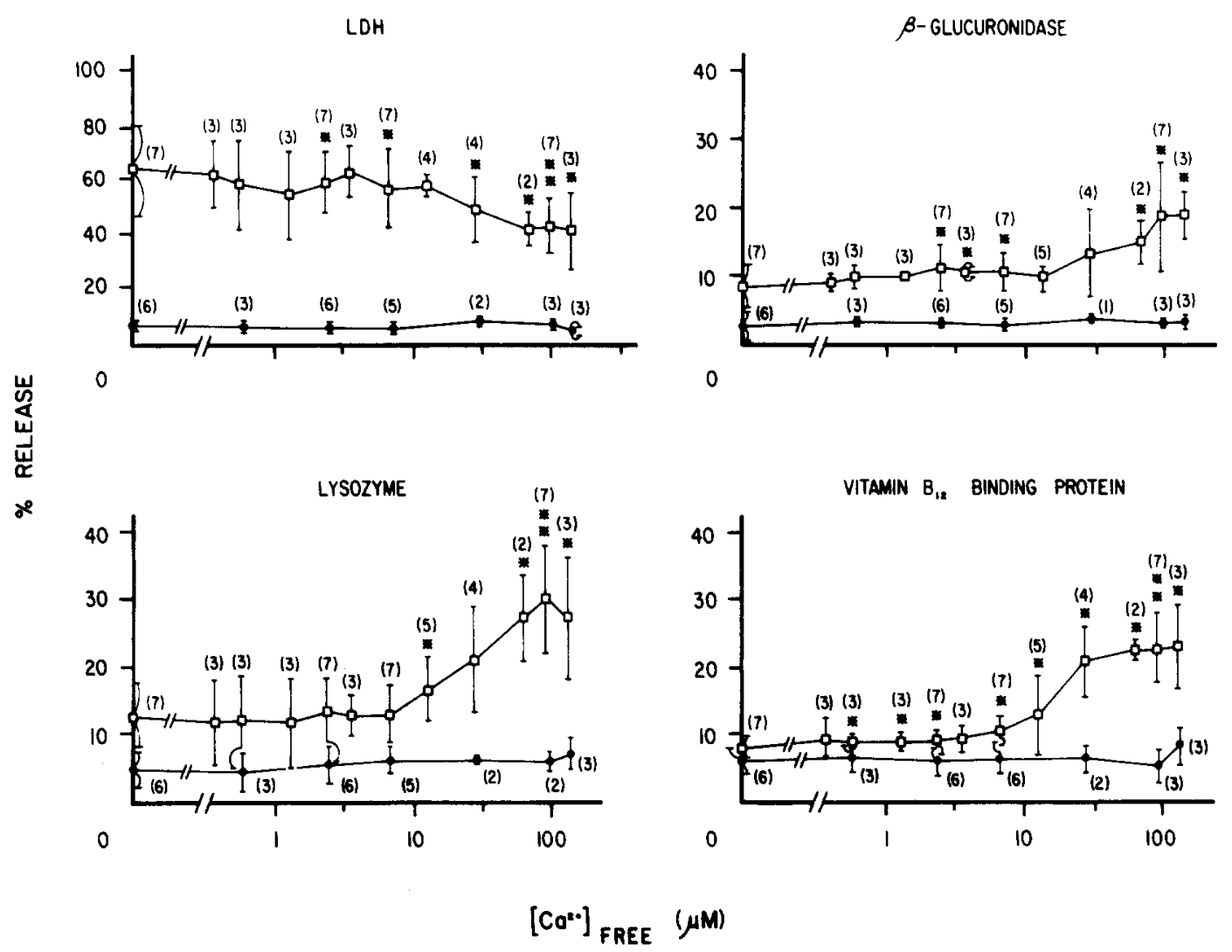

Fig. 6. Effect of free-calcium concentration on the release of lysosomal constituents from permeabilized and untreated neutrophils. Human neutrophils were preincubated with digitonin $(10 \mu \mathrm{g} / \mathrm{ml})$ for $25 \mathrm{~min}$ at $37^{\circ} \mathrm{C}$ after which they were incubated with the indicated concentrations of free calcium for an additional $10 \mathrm{~min}$ at $37^{\circ} \mathrm{C}$. The results show the means $( \pm \mathrm{S}$.D.) for the number of separate experiments shown in parentheses. Statistical significance was assessed using the Student's paired $t$-test; ${ }^{*}$ indicates $P<0.05$ and ** indicates $P<0.01$. Release of cellular constituents is shown for both untreated (-๑) and digitonin-permeabilized $(\square-\square)$ neutrophils. LDH, lactate dehydrogenase.

tion. When $\left[{ }^{14} \mathrm{C}\right]$ EDTA was used as the tracer, only $50 \%$ reversibility was obtained at $1 \cdot 10^{-4} \mathrm{M}$ $\mathrm{Ca}^{2+}$. This was comparable to the reversibility seen for Trypan blue. Lower concentrations of $\mathrm{Ca}^{2+}$ produced less reversibility of permeabilization. The quantities of EDTA employed as a tracer in these studies had no effect on free-calcium concentrations or upon the exclusion of $\left[{ }^{14} \mathrm{C}\right]$ insulin.

\section{Morphology}

The morphology of neutrophils exposed to the permeabilization system was also examined. Fig. 9 shows a neutrophil suspended in buffer B without digitonin. We have observed the preservation of delicate ultrastructure, such as the Golgi apparatus, as well as a clear definition between euchromatin and heterochromatin in the nucleus.

Fig. 10A shows two neutrophils which have been exposed to digitonin and which are representative of the two distinct morphologies found in this heterogeneous population. After $25 \mathrm{~min}$ in buffer B plus digitonin, some of the cells retained morphologic characteristics suggestive of nonpermeabilized cells (Fig. 10A, left), including a dense cytoplasmic matrix and clearly demarcated nuclear chromatin. The other cells, however, were observed to have a more electron-lucent cytoplasm, and rounder and less dense nuclear material (Fig. $10 \mathrm{~A}$, right). We believe that these traits suggest 


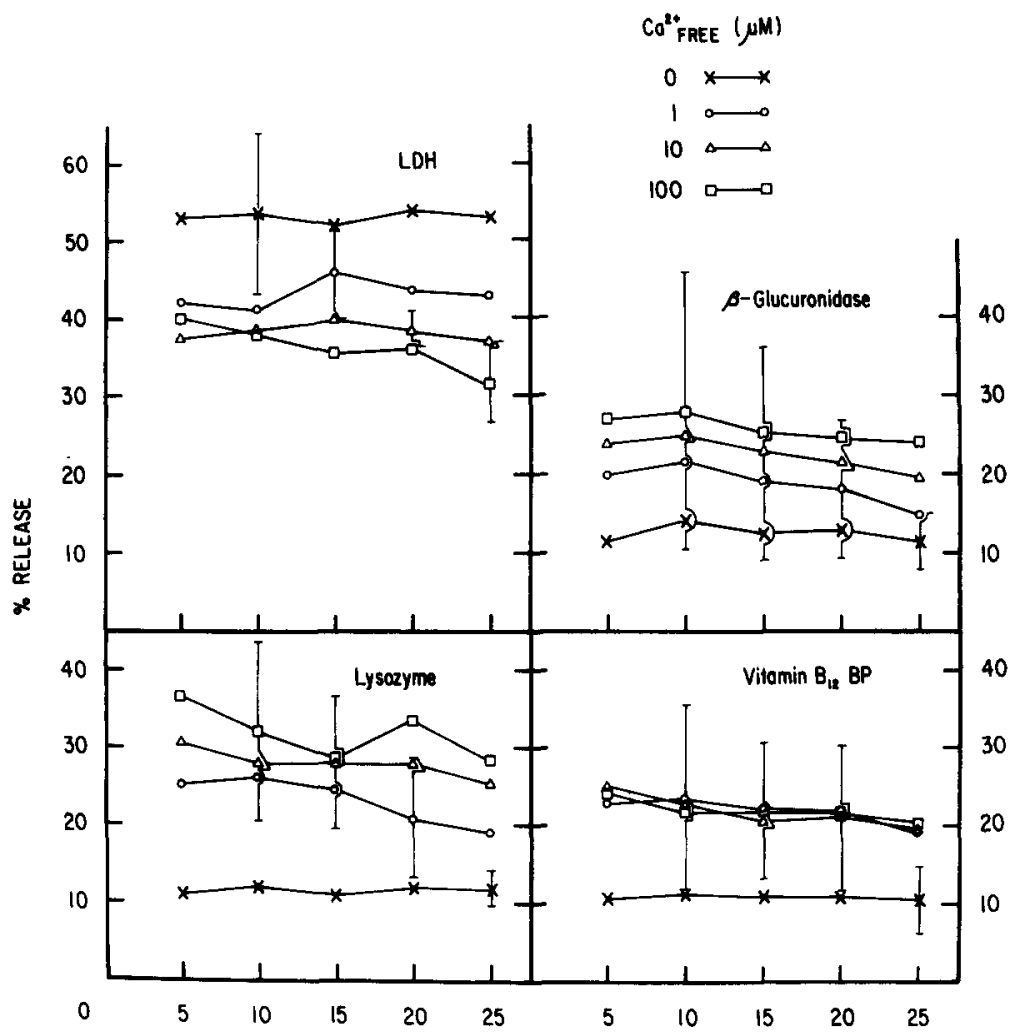

CELL CONCENTRATION $\left(10^{1 / m l}\right)$
Fig. 7. Effect of cell concentration on release of enzymes from permeabilized neutrophils. Human neutrophils were permeabilized with $10 \mu \mathrm{g} / \mathrm{ml}$ digitonin for $25 \mathrm{~min}$ at $37^{\circ} \mathrm{C}$. The cells were resuspended at the indicated concentrations and then exposed to one of the four free-calcium levels shown. The results are means $( \pm$ S.D.) for three separate experiments. To avoid graphic clutter, each $\mathrm{Ca}^{2+}$ concentration curve has a single error bar, which represents the simple average for the errors in that set of five points. LDH, lactate dehydrogenase.

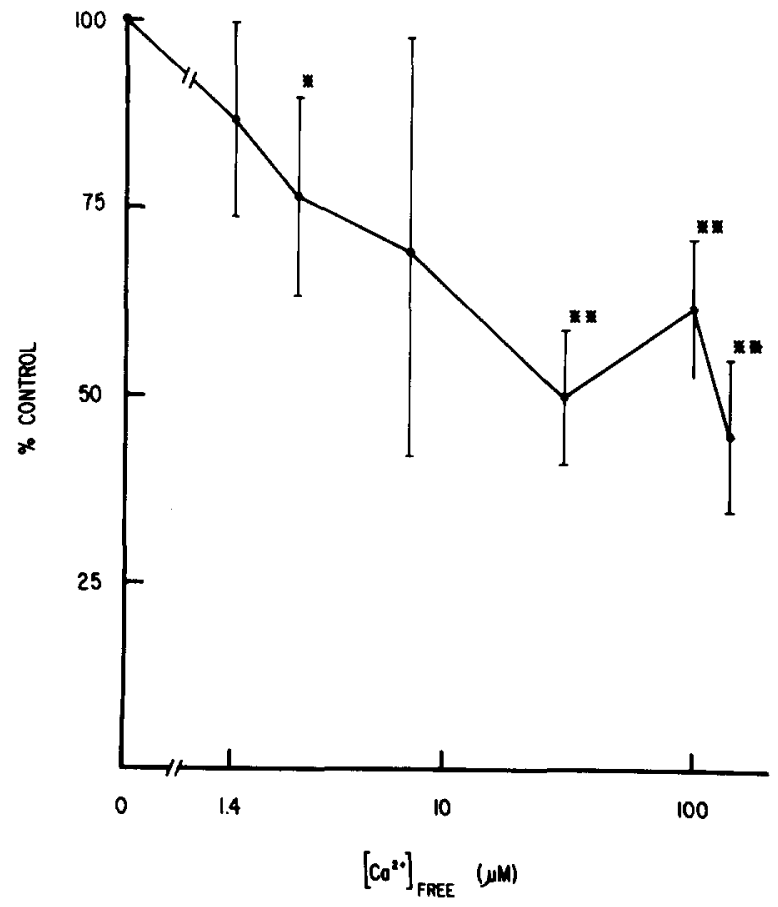

digitonin permeabilization. Cellular permeabilization by digitonin under these conditions did not appear to extensively damage labile cellular contents, however, since intact Golgi (Fig. 10C) with associated vesicles, and cytoplasmic granules with complete membranes (Fig. 10B) were routinely observed.

Although morphologic structure was not damaged by permeabilization, we observed a rearrangement of cellular contents. Cells permeabilized with digitonin, but without exposure to $\mathrm{Ca}^{2+}$,

Fig. 8. Effect of free-calcium concentration on the permeability of neutropbils as determined by Trypan blue. Neutrophils were permeabilized with digitonin $(10 \mu \mathrm{g} / \mathrm{ml})$ and then incubated 10 min at $37^{\circ} \mathrm{C}$ with the indicated concentration of $\mathrm{Ca}^{2+}$. They were incubated $10 \mathrm{~min}$ with Trypan blue and the proportions of cells positive for the dye were counted. The control was defined as that proportion measured for cells which were not exposed to $\mathrm{Ca}^{2+}$. The results are given as means $( \pm$ S.D.) for three experiments. Statistics were calculated by Student's paired $t$-test. ${ }^{*} P<0.05,{ }^{* *} P<0.01, n=3$. 


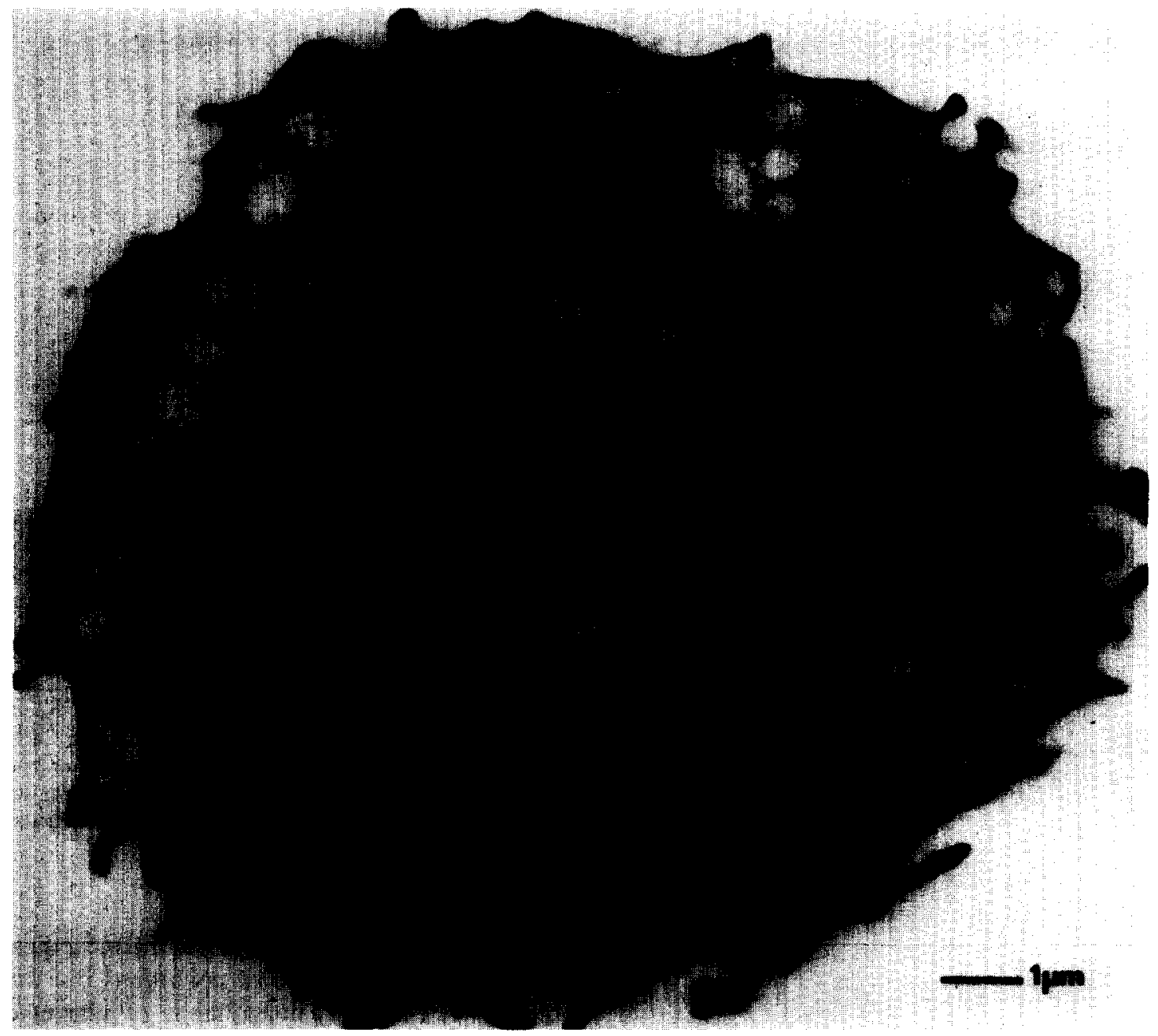

Fig. 9. Morphology of neutrophils suspended in buffer B. Human peripheral blood neutrophils were suspended in buffer B and then prepared for electron microscopy. Neutrophils in buffer B display good retention of cellular organization, wihout gross distortions in organelle morphology. The golgi (G), for example, shows preservation of its stacked cysternae. G, golgi; N, nucleus; Magnification, $\times 19900$.

appeared to have their cytoplasmic granules arranged either randomly or more centrally located (Fig. 10A, 11A). Following exposure to $\mathrm{Ca}^{2+}$, most cellular granules appeared to be located closer to the plasma membrane (Fig. 11B). Indeed, many of these cells contained arrays of both specific and azurophil granules in close proximity to the cytoplasmic aspect of the plasma membrane (Fig. 11C, arrows). Some images suggest exocytosis of granule contents, since granules and plasma membranes appear closely applied and sometimes continuous (Fig. 11D, arrows). 


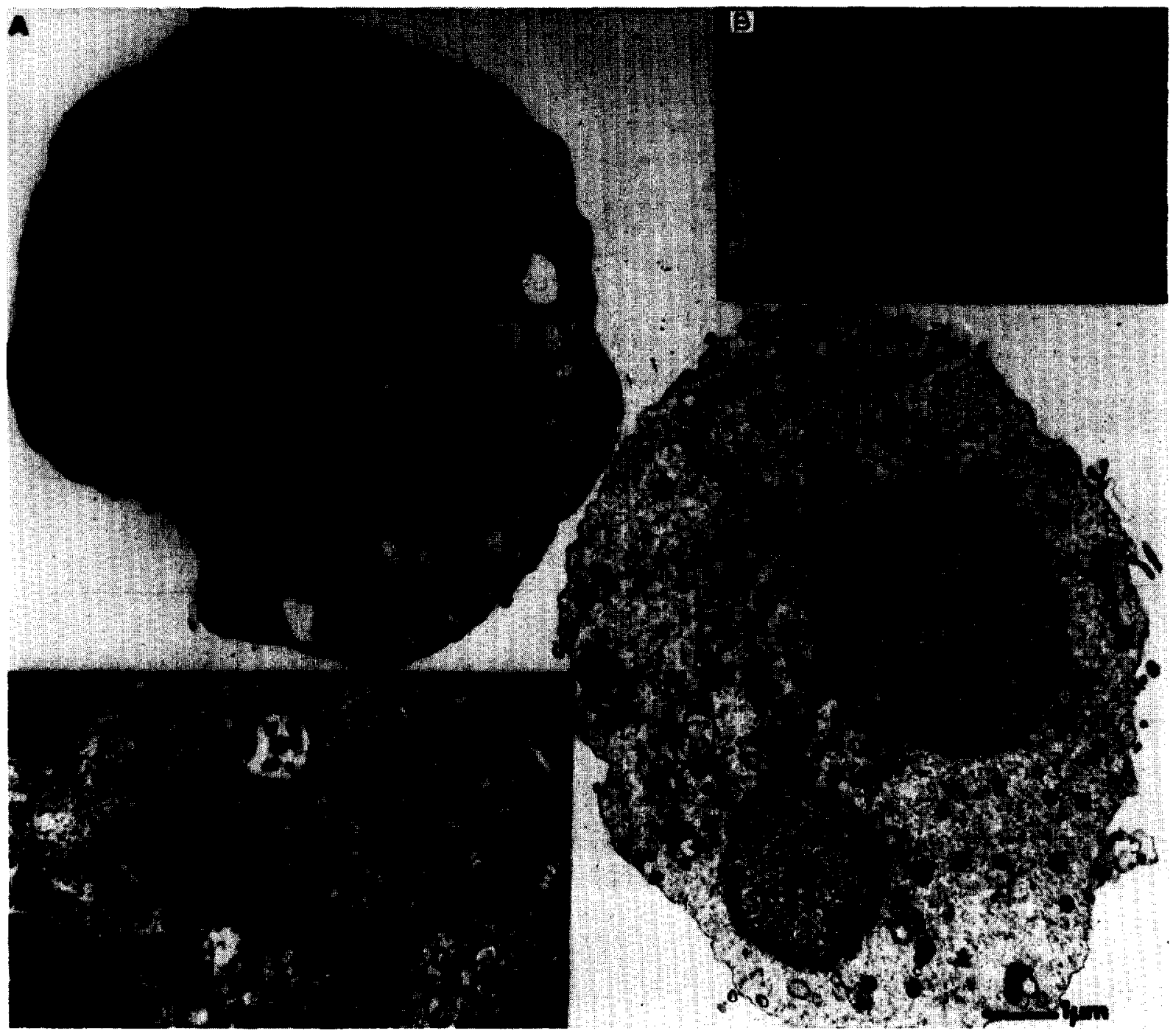

Fig. 10. Effect of permeabilization on neutrophil morphology. Human neutrophils were permeabilized in buffer $\mathrm{B}$ plus $10 \mu \mathrm{g} / \mathrm{ml}$ digitonin, and prepared for electron microscopy. Some of the cells displayed normal characteristics (A, left), including clearly defined nuclear chromatin and an electron-dense cytoplasmic matrix. Most cells, however, showed evidence of permeabilization (A, right) by a change in the opacity of the cytoplasm and a loss of chromatin definition. In the permeabilized state, cells retained excellent morphologic preservation; Golgi (G, in part $\mathrm{C}$ ) with complete cysternae and associated vesicles were routinely observed, and cytoplasmic granules (B) often had complete membranes. N, nucleus; G, golgi; Gr, cytoplasmic granules; ER, endoplasmic reticulum; $\mathrm{v}$, vesicle. Magnifications: $\mathrm{A}, \times 10697$; B, $\times 61989 ; \mathrm{C}, \times 31086$.

\section{Discussion}

Permeabilization has been used in a variety of cell systems [17-24] to demonstrate a direct role for intracellular free calcium in stimulus-secretion coupling. The means whereby permeabilization is achieved are diverse, but the use of digitonin is relatively common [20-23]. While the precise conditions vary with experimental protocol, particularly with respect to cell concentration and the presence of calcium during the permeabilization procedure, it should be noted that the conditions 

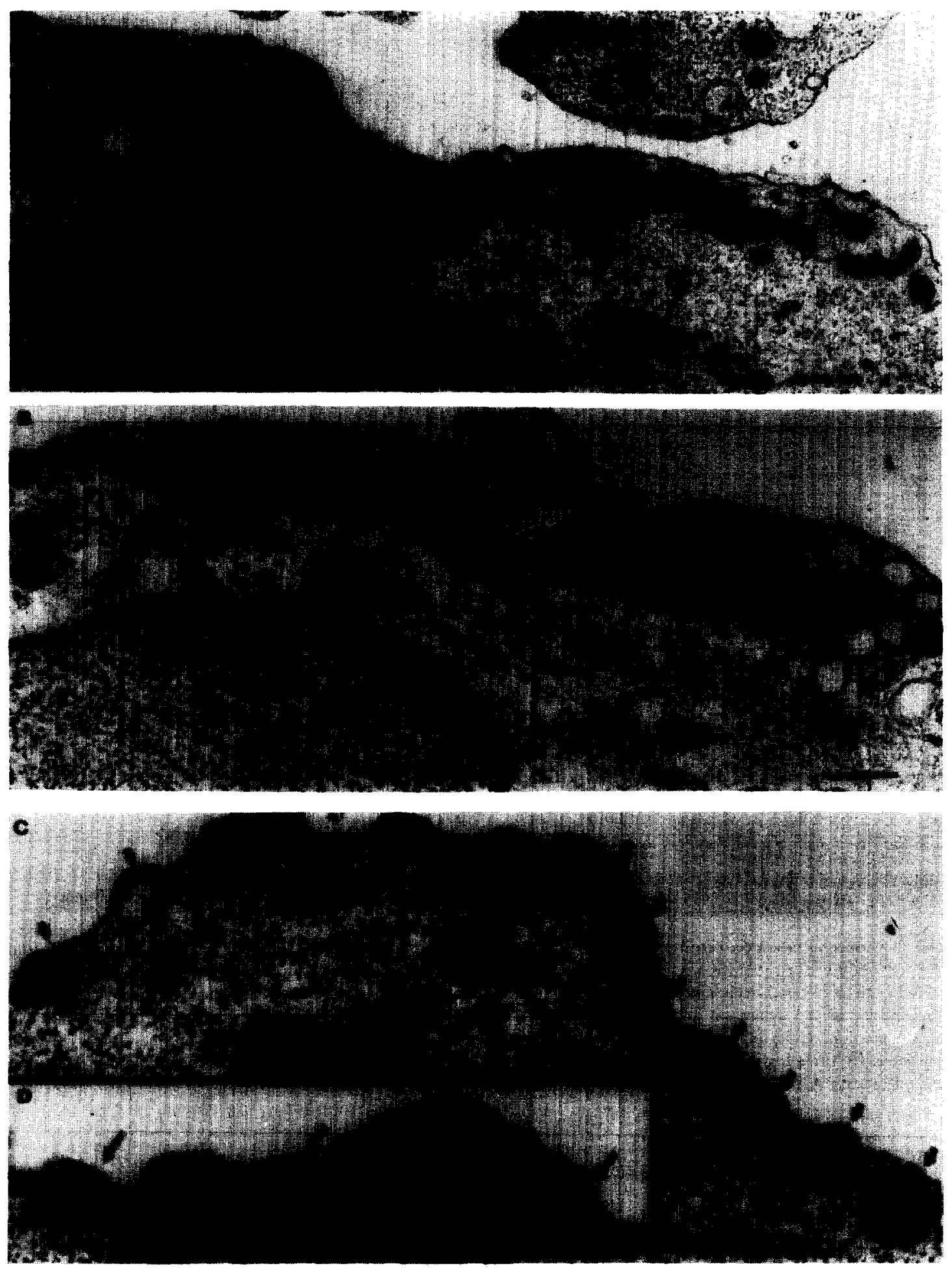
employed in our experiments are quite typical [20-23]. In this regard, Prentki et al. [23] recently reported the permeabilization of human neutrophils with digitonin in a high-sodium medium. Results were apparently much the same as ours, as they obtained $62 \%$ lactate dehydrogenase release and thus, most likely, a heterogeneous population. However, our granules appeared to be considerably more intact, as indicated by retention of vitamin B-12 binding protein.

Our data demonstrate that the permeabilization process in human neutrophils is dependent upon a number of variables. The concentration of digitonin was crucial; permeabilization, as monitored by both radiochemical tracers and lactate dehydrogenase release, increased until it reached a plateau at a digitonin concentration of $10 \mu \mathrm{g} / \mathrm{ml}$. The time period allowed for permeabilization, as measured by both these parameters, was also critical. Finally, temperature was very important for the permeabilization process, although it was less critical for calcium-induced lysosomal enzyme release.

There are a number of potential difficulties with interpretation of the results presented here. For example, it has been shown that digitonin is a $\mathrm{Ca}^{2+}$-dependent stimulus for secretion by neutrophils [33-34]. However, these previously published experiments were performed in physiologic, high-sodium buffers containing calcium, not in buffer B. High-sodium buffers are conducive to secretion while buffer B is not (Fig. 6). It can be seen throughout our data that digitonin does increase the baseline release of all lysosomal enzymes, generally by 2 -fold, but this is most likely due to some lysis of granule membranes by the detergent. What is most important is that micromolar concentrations of free calcium triggered substantial quantities of enzyme release. Furthermore, Fig. 3 shows that increasing periods of incubation with digitonin (and thus increased per- meabilization as monitored by lactate dehydrogenase release) must be employed before calcium can induce secretion; this demonstrates that there is no simple synergy between digitonin and calcium which produces lysosomal enzyme release. Finally, digitonin is not serving as a general 'priming' stimulus, since it does not augment enzyme release stimulated by optimal or suboptimal concentrations of PMA, Concanavalin A, or fMet-Leu-Phe (data not shown).

The possibility also exists that calcium is actually inducing lysis of the granules rather than secretion. This is an extremely unlikely occurrence since calcium is known to stabilize rather than labilize the membranes of permeabilized cells [17-19]; indeed, our data suggest that micromolar levels of free calcium actually caused resealing of the permeabilized neutrophils (Figs. 2 and 8). In addition, granule membranes appeared to be preserved in permeabilized cells (Figs. 10 and 11) and morphology suggestive of degranulation has been observed (Fig. 11). We have also provided strong evidence that a lytic mechanism is not operating, since granule enzymes released by such a process would not be able to escape from resealed neutrophils (which could no longer leak lactate dehydrogease or permit entry of inulin (Fig. 2)). Rather, this appears to be a case of classic secretion in which lysosomal constituents are discharged without the accompanying release of cytoplasmic contents.

The resealing process induced by $\mathrm{Ca}^{2+}$ could conceivably allow the neutrophil to reconstitute its intracellular space, such as by operation of its $\mathrm{Ca}^{2+}$ pump. However, this is unlikely to present a difficulty in interpretation since we have found that resealing is partial, and applies only to highmolecular-weight $\left(M_{\mathrm{r}}>5000\right)$ solutes, such as inulin and lactate dehydrogenase (Fig. 2); smaller solutes, such as EDTA and Trypan blue, were not excluded (Fig. 8). Thus it is very unlikely that the

Fig. 11. Effect of calcium on morphology of permeabilized neutrophils. Human peripheral neutrophils were permeabilized and then incubated with or without $30 \mu \mathrm{M} \mathrm{Ca}^{2+}$ for $10 \mathrm{~min}$ before being prepared for electron microscopy. Before the addition of $\mathrm{Ca}^{2+}(\mathrm{A})$, intracellular azurophil $(\mathrm{Ag})$ and specific granules $(\mathrm{Sg})$ remained uniformly and randomly distributed in the cytoplasm. After the addition of $30 \mu \mathrm{M} \mathrm{Ca}^{2+}$, granules attained a position closer to the plasma membrane (B). Many images of these cells contained arrays of granules closely applied to the plasma membrane (Arrows, C), including some which suggested degranulation events, since granule and plasma membranes appeared continuous (Arrows, D and ${ }^{*} \mathrm{C}$ ). $\mathrm{N}$, nucleus; Cy, cytoplasm; $\mathrm{Ag}$, azurophil granule; $\mathrm{Sg}, \mathrm{specific}$ granule. Magnifications: A, $\times 33700 ; \mathrm{B}, \times 33700 ; \mathrm{C}, \times 68500 ; \mathrm{D}, \times 58000 ; \mathrm{Bar}=0.5 \mu \mathrm{M}$. 
'resealed' cell would be able to change its internal environment with respect to small constituents such as $\mathrm{Ca}^{2+}$.

A final difficulty with this system is the day-today variability of permeabilization, evident in Table I. As yet, we have been unable to determine the source of this phenomenon. Heterogeneity of the cell population is strongly suggested by Trypan blue permeability (data not shown) and morphology; the fraction of permeabilized cells determined by both of these criteria agrees quantita. tively with lactate dehydrogenase leakage. Nonetheless, the magnitude of this difficulty is minimized by the fact that calcium-induced lysosomal enzyme release is always obtained and that it is always statistically significant. It is also useful to note that responsiveness to calcium correlated with the degree of permeabilization, as monitored by the release of lactate dehydrogenase (Table II). While the degree of permeabilization is variable, it does serve as an accurate predictor of the amount of calcium-induced lysosomal enzyme release which will be obtained.

Digitonin has several advantages over saponin, which we previously employed as a permeabilization agent. First, digitonin is a defined substance, while saponin is a mixture of compounds; digitonin should thus provide more reproducible results among batches. Second, the digitonin system was less sensitive to detergent concentration. Using saponin, it is easy to lyse the cells due to relatively small variations $(20 \%)$ in cell/detergent ratio [24]. The range of digitonin concentrations over which permeabilization could be achieved without lysis of the cells was much broader. Finally, permeabilization with digitonin permitted calcium-induced secretion of azurophil granule constituents (i.e., $\beta$-glucuronidase) this was never observed with the saponin system. The reason for this is unknown, although presumably treatment with digitonin preserves the stimulus-secretion coupling pathway for this granule type. It is possible, for example, that saponin allows certain important proteins to be denatured or lost to the extracellular space. A comparison between these two permeabilized cell systems could provide crucial information with respect to the two stimulussecretion pathways.

These studies complement those employing in- direct probes of intracellular free calcium. Using chlortetracycline, it has been suggested that membrane-bound calcium is rapidly mobilized following stimulation [9-11]. Studies with quin2 have suggested that intracellular free calcium levels increase as a result of this utilization, reaching submicromolar or micromolar levels $[12,13]$. Our data demonstrate that free-calcium levels in the micromolar range are alone sufficient to induce secretion. This calcium-induced secretion appears physiologic with respect to quantity and time-course. It also is independent of cytochalasin B and a variety of other potential cofactors. As indicated in Fig. 6, it appears that release of constituents from specific granules is more sensitive to calcium than release from azurophil granules, a conclusion which has long been suspected [35]. While it could be argued that intracellular free-calcium levels as monitored by quin 2 are a little lower than those employed in this study, it should be realized that this probe monitors only average levels of calcium. Indeed, it has recently been reported, that quin 2 reduces the height of the intracellular free-calcium transient by its mere presence [36]; thus, peak levels could be considerably higher than generally reported.

These results thus demonstrate that micromolar levels of free calcium are alone sufficient to induce lysosomal enzyme release. Whether or not that is the actual or sole mechanism in the intact cell is not clear. It is quite possible that physiologic intracellular free-calcium levels do not reach the range required for this model system. If no cofactors could then be found to alleviate the $\mathrm{Ca}^{2+}$ requirement, then it is also possible that this mechanism is not operating in vivo. Even under this worst case situation, our data nonetheless show that a degranulation system totally dependent upon free $\mathrm{Ca}^{2+}$ is extant in the cells; this could, for example, be the vestigial remains of a primitive fusion mechanism which requires higher $\mathrm{Ca}^{2+}$ concentrations. Future experiments will concentrate on investigation of this as well as on utilization of the resealing process for more extensive probes of the intracellular space.

\section{Acknowledgements}

This work was supported by NIH grants AI20065 and HL31963. J.E.S. is a Senior Fellow 
of the Arthritis Foundation. We wish to thank Joseph Mailloux for his work on the electron microscopy. Finally, special regards go to Kenneth Balazovich for his invaluable work on preparing the plates.

\section{References}

1 Korchak, H.M. and Weissmann, G. (1978) Proc. Natl. Acad. Sci. (USA) 75, 3818-3822

2 Seligmann, B.F., Gallin, E.K., Martin, D.L., Shain, W. and Gallin, J.T. (1980) J. Membrane Biol. 52, 257-272

3 Naccache, P.H., Showell, H.J., Becker, E.L., and Sha'afi, R.I. (1977) J. Cell Biol. 75, 635-649

4 Naccache, P.H., Showell, H.J., Becker, E.L. and Sha'afi, R.I. (1977) J. Cell Biol. 73, 428-444

5 Korchak, H.M., Rutherford, L.F. and Weissmann, G. (1984) J. Biol. Chem. 259, 4070-4075

6 Korchak, H.M., Vienne, K., Rutherford, I.F., Wilkenfeld, C., Finkelstein, M.C. and Weissmann, G. (1984) J. Biol. Chem. 259, 4076-4082

7 Smolen, J.E., Korchak, H.M. and Weissmann, G. (1980) J. Clin. Invest. 65, 1077-1085

8 Simchowitz, I., Fischbein, I.C., Spilberg, T. and Atkinson, J.P. (1980) J. Immunol. 124, 1482-1491

9 Naccache, P.H., Showell, H.J., Becker, E.L. and Sha'afi, R.I. (1979) J. Cell Biol. 83, 179-186

10 Smolen, J.E. and Weissmann, G. (1982) Biochim. Biophys. Acta $720,172-180$

11 Smolen, J.E., Eisenstat, B.A. and Weissmann, G. (1982) Biochim. Biophys. Acta 717, 422-431

12 White, J.R., Naccache, P.H., Molski, T.F.P., Borgeat, P. and Sha'afi, R.I. (1983) Biochem. Biophys. Res. Comm. 113, 44-50

13 Pozzan, T., Lew, D.P., Wollheim, C.B. and Tsein, R.Y. (1983) Science 221, 1413-1415

14 Lagast, H., Pozzan, T., Lew, P.D. and Waldvogel, F.A. (1983) J. Clin. Res. 31, 410a

15 Sha'afi, R.I., White. J.R., Molski, T.F.P., Shefcyk, J., Volpi,
M., Naccache, P.H. and Feinstein, M.B. (1983) Biochem. Biophys. Res. Comm. 114, 638-645

16 Niedel, J.F., Kuhn, L.J. and Vandenbark, G.R. (1983) Proc. Natl. Acad. Sci. U.S.A. 80, 36-40

17 Gomperts, B.D., Baldwin, J.M. and Micklem, K.J. (1983) Biochem. J. 210, 737-745

18 Bennett, J.P., Cockcroft, S. and Gomperts, B.D. (1981) J. Physiol. 317, 335-345

19 Hirata, M. and Koga, T. (1982) Biochem. Biophys. Res. Comm. 104, 1544-1549

20 Dunn, L.A. and Holz, R.W. (1983) J. Biol. Chem. 258, 4989-4993

21 Weigel, P.H., Ray, D.A. and Oka, J.A. (1983) Anal. Biochem. 133, 437-449

22 Lumas, M., Galvan, A., Solano, P. and Goberna, R. (1983) Biochim. Biophys. Acta 731, 129-136

23 Prentki, M., Wollheim, C.B. and Lew, P.D. (1984) J. Biol. Chem. 259, 13777-13782

24 Smolen, J.E. and Stoehr, S.J. (1985) J. Immunol. 134, 1859-1865

25 Boyum, A. (1968) Scand. J. Clin. Lab. Invest. 21, 77-89

26 Zurier, R.N., Hoffstein, S. and Weissmann, G. (1973) Proc. natl. Acad. Sci. USA 70, 844-848

27 Brittinger, G.R., Hirschhorn, R., Douglas, S.D. and Weissmann, G. (1968) J. Cell Biol. 37, 394-411

28 Worthington Enzyme Manual, Worthington Biochem. Co., Freehold, NJ, 1972, p. 100

29 Smith, G.P. and Peters, T.J. (1982) Biochim. Biophys. Acta 719, 304-308

30 Wacker, W.F.C., Ulmer, O.O. and Vallee, R.L. (1956) N.E.J. Med. 255, 449-456

31 Bers, O.M. (1982) Am. J. Physiol. 242, C404-C408

32 Graham, R.C., Karnovsky, M.J., Shafer, A.W., Glass, E.A. and Karnovsky, M.L. (1967) J. Cell Biol. 32, 629-647

33 Cohen, H.J. and Chovaniec, M.E. (1978) J. Clin. Invest. 61, 1081-1087

34 Cohen, H.J. and Chovaniec, M.E. (1978) J. Clin. Invest. 61, 1088-1096

35 Goldstein, J.M., Horn, J.K., Kaplan, H.B. and Weissmann, G. (1974) Biochem. Biophys. Res. Comm. 60, 807-812

36 Lew, P.D., Wollheim, C.B., Waldvogel, F.A. and Pozzan, T. (1984) J. Cell Biol. 99, 1212-1220 